\title{
Antibacterial Potential of Jatropha sp. Latex against Multidrug-Resistant Bacteria
}

\author{
Muhammad Evy Prastiyanto $\left(\mathbb{D},{ }^{1,2}\right.$ Prayoda Deri Tama, ${ }^{3}$ Ninda Ananda, ${ }^{3}$ Wildiani Wilson, ${ }^{1}$ \\ and Ana Hidayati Mukaromah ${ }^{4}$ \\ ${ }^{1}$ Microbiology Laboratory, Department of Medical Laboratory Technology, Universitas Muhammadiyah Semarang, \\ Kedungmundu Raya Street 18, Semarang 50273, Indonesia \\ ${ }^{2}$ Indonesian Medicinal Laboratory Science, Kedungmundu Raya Street 18, Semarang 50273, Indonesia \\ ${ }^{3}$ Bachelor Program Department of Medical Laboratory Technology, Faculty of Nursing and Health Science, \\ Universitas Muhammadiyah Semarang, Kedungmundu Raya Street 18, Semarang, Indonesia \\ ${ }^{4}$ Chemistry Laboratory, Department of Medical Laboratory Technology, Universitas Muhammadiyah Semarang, \\ Kedungmundu Raya Street 18, Semarang 50273, Indonesia
}

Correspondence should be addressed to Muhammad Evy Prastiyanto; evy_prastiyanto@unimus.ac.id

Received 19 October 2019; Revised 15 June 2020; Accepted 1 July 2020; Published 27 August 2020

Academic Editor: Giuseppe Comi

Copyright (C) 2020 Muhammad Evy Prastiyanto et al. This is an open access article distributed under the Creative Commons Attribution License, which permits unrestricted use, distribution, and reproduction in any medium, provided the original work is properly cited.

Objective. This study was aimed to evaluate the antibacterial activity of the latex of three species members of Jatropha (J. curcas, J. gossypilofia Linn., and J. multifida) against methicillin-resistant Staphylococcus aureus (MRSA), extended-spectrum beta-lactamase(ESBL-) producing Escherichia coli and ESBL-producing Klebsiella pneumonia, carbapenemase-resistant Enterobacteriaceae (CRE)-E. coli, K. pneumoniae-carbapenemase (KPC), and carbapenemase-resistant Pseudomonas aeruginosa (CRPA). Method. The antibacterial activities were calculated based on the inhibition zones using the Mueller-Hinton agar diffusion method, minimum inhibitory concentration (MIC) using Mueller-Hinton broth in a microdilution method, and minimum bactericidal concentration (MBC) using blood agar plate. Results. The latex of Jatropha showed antibacterial activities against the MRSA and CRPA. All latex of Jatropha appeared to have the antibacterial activities against MRSA and CRPA in the diffusion method (20.4-23.7 mm and 12-15 mm), MIC (0.19-6.25\%, and 25\%), and MBC (0.39-12.5\% and 50\%). Phytochemical screening of latex indicated the presence of flavonoids. Conclusions. The latex of J. curcas, J. gossypilofia Linn., and J. multifida has the potential to be developed as antibacterial agents, especially against MRSA and CRPA strain, but further in vivo research and discovery of the mode of its action are required to shed the light on the effects.

\section{Introduction}

Bacterial resistance to antibiotics has become a serious problem in the world, including in Indonesia. This is a factor in the high mortality rate and continues to increase every year [1]. Inappropriate use of antibiotics is one of the causes of antibiotic resistance [2]. The emergence of multidrugresistant (MDR) bacteria causes treatment ineffectiveness [3]. This has a devastating effect on patients suffering from MDR bacterial infections, increasing the treatment costs, which become increasingly high and difficult to afford and causing prolonged illness and even death [4]. One alternative to overcome these problems is to use natural ingredients such as materials from fungi [5] and plants [6], one of which is Jatropha.

Our study aimed to investigate the antibacterial activities of Jatropha latex against MDR bacteria. In this study, we used three species of Jatropha plants to measure the antibacterial activities against MDR bacteria such as methicillin-resistant Staphylococcus aureus (MRSA), extended-spectrum beta-lactamase (ESBL)-producing Escherichia coli, ESBL-producing Klebsiella pneumonia, carbapenemase-resistant Enterobacteriaceae (CRE)-E. coli, K. pneumoniae-carbapenemase (KPC), and carbapenemase-resistant Pseudomonas aeruginosa (CRPA). Three types of latex used in this study were Jatropha curcas, Jatropha gossypilofia Linn., and Jatropha multifida. 


\section{Methods}

2.1. Collection of Latex. Jatropha was collected from the field of Universitas Muhammadiyah Semarang in Semarang at the rainy season in January 2019. The collected plants were identified and classified according to the types of Herbarium Semarangense at the Department of Biology, Universitas Negeri Semarang. The latex of J. curcas, J. gossypilofia Linn., and J. multifida was collected by cutting the stems. The latex was stored in sterile dark bottles.

2.2. Materials. The used materials were Autoclave (Hirayama HICLAV HV-25), Incubator (WTC Binder), biological safety cabinet (Labconco Purifier Class II Biosafety Cabinet), freezer (Electrolux), densimat (Biomerieux), Mueller Hinton Agar (MHA), Mueller Hinton Broth (MHB), Blood Agar Plate (BAP), McFarland, MRSA, ESBLproducing Escherichia coli, ESBL-producing Klebsiella pneumonia, CRE-E. coli, KPC, and CRPA that were obtained from the Medical Microbiology Laboratory of dr. Kariadi Central Hospital, Semarang, Central Java, Indonesia. MDR isolates were identified, and the susceptibility patterns were obtained using Vitek ${ }^{\circledR}$ MS (BioM'erieux).

2.3. Bacterial Preparation. The tested organisms were subcultured BAP for $24 \mathrm{~h}$ at $(35 \pm 2)^{\circ} \mathrm{C}$. The colonies were inoculated in a normal saline solution. The bacteria cell suspensions were homogenized and adjusted to 0.5 McFarland standards $\left(1.5 \times 10^{8} \mathrm{CFU} / \mathrm{mL}\right)$ using a densimat.

\subsection{Antibacterial Assay of Latex}

2.4.1. Agar Well Diffusion Assay. The antibacterial activities of latex were evaluated using agar well diffusion assay [7, 8]. In this method, $100 \mu \mathrm{L}$ of each test organism, which was equivalent to a $0.5 \mathrm{McF}$ arland standard, was inoculated on the MHA. Then, it was spread on to the surface of the agar using a sterilized glass spreader. After 10 minutes of inoculation, the wells were prepared using a sterilized steel cork borer ( $1 \mathrm{~cm}$ in diameter). Wells were made on each plate, out of which three wells were loaded with each latex. Each test was done in triplicate. All the plates were then incubated aerobically at $35 \pm 2^{\circ} \mathrm{C}$ for $16-20 \mathrm{~h}$. The antibacterial activities were evaluated by measuring the diameters of zones of inhibition $(\mathrm{mm})$ against the test organism.

2.4.2. Minimum Inhibitory Concentration (MIC) and Minimum Bactericidal Concentration (MBC). The MIC of Jatropha latex was determined using Mueller-Hinton broth microdilution [9]. MIC determination was performed by a serial dilution technique using 12-well microtiter plates. MHB $(100 \mu \mathrm{L})$ was placed into the well/plate and Jatropha latex $(100 \mu \mathrm{L})$ in the dilution series. $10 \mu \mathrm{L}$ bacterial cell suspensions were placed in each well/plate. Microplates were incubated aerobically at $35 \pm 2{ }^{\circ} \mathrm{C}$ for $16-20 \mathrm{~h}$. The lowest concentrations without visible growth completely inhibited the bacteria (MIC) [10]. The MBC was defined as the lowest concentration of the extract that did not allow any growth [10]. The MBC of Jatropha latex was determined following the methods described by [11] with slight modifications. Wells were subcultured using a $10 \mu \mathrm{L}$ inoculating loop on to a $5 \%$ sheep BAP at $(35 \pm 2)^{\circ} \mathrm{C}$ for $16-20 \mathrm{~h}$ incubation.

2.5. Phytochemical Screening. The Jatropha latex was screened for the presence of different classes of secondary metabolites, including alkaloids and flavonoids, using previously described methods [12].

\section{Results}

3.1. Agar Well Diffusion Assay. The antibacterial activities of three Jatropha species were examined in vitro using the diffusion and dilution of six MDR bacteria. Figure 1 shows that all latex exhibited inhibition zones against MRSA and CRPA. J. curcas showed a greater inhibitory zone diameter of $23.7 \mathrm{~mm}$ against MRSA and $15 \mathrm{~mm}$ against CRPA (Table 1).

3.2. Minimum Inhibitory Concentration (MIC) and Minimum Bactericidal Concentration (MBC). The antibacterial activities of the Jatropha latex (J. curcas, J. gossypilofia Linn., and J. multifida) were assayed in vitro by the agar microdilution method against MRSA and CRPA. Table 2 demonstrates that among the three Jatropha latex, J. multifida exhibited the smallest value of MIC and MBC against MRSA (0.19\% and $0.39 \%)$. Figures 2-4 show that J. curcas and J. gossypilofia Linn. had the same activities against MRSA. Table 2 displays that all latex exhibited the same value of MIC and MBC against CRPA (25\% and 50\%). Figures 5-7 exhibit that $J$. curcas, J. gossypilofia Linn., and J. multifida had the potential to be developed as antibacterial agents for MRSA and CRPA strains.

3.3. Phytochemical Analysis. The secondary metabolites are presented in Table 3. Flavonoids are present in all Jatropha latex.

\section{Discussion}

The research for new antibacterial agents from a natural or organic source has become a very important endeavor, considering the escalating levels of antibiotic resistance. One of the efforts in this research is focused on the use of Jatropha latex, which is widely available. Traditional medicine has been practiced worldwide, including in Indonesia, for centuries.

The agar well diffusion and microdilution methods were used in the present study due to their routine use as a quantitative method in clinical laboratories. In the agar well diffusion method, $100 \mu \mathrm{L}$ of each MDR organism, equal to a $0.5 \mathrm{McF}$ arland standard, was inoculated on the MHA. The wells were prepared using a sterilized teel cork borer $(1 \mathrm{~cm}$ diameter). Wells were made on each plate, out of which three wells were loaded with each of latex. All the plates were then incubated at $35 \pm 2{ }^{\circ} \mathrm{C}$ for $16-20 \mathrm{~h}$. Antibacterial activities were evaluated by measuring the diameters of zones of 


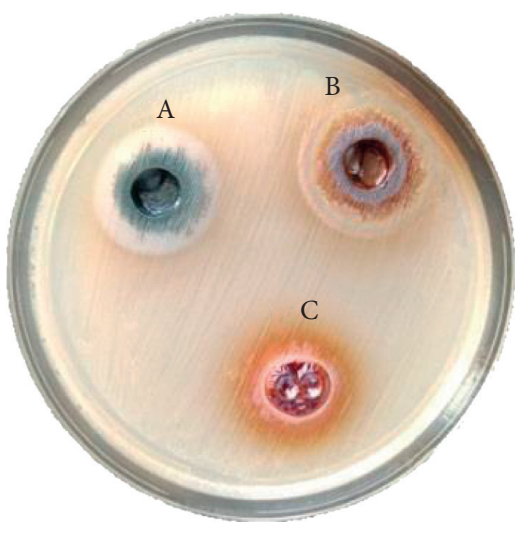

(a)

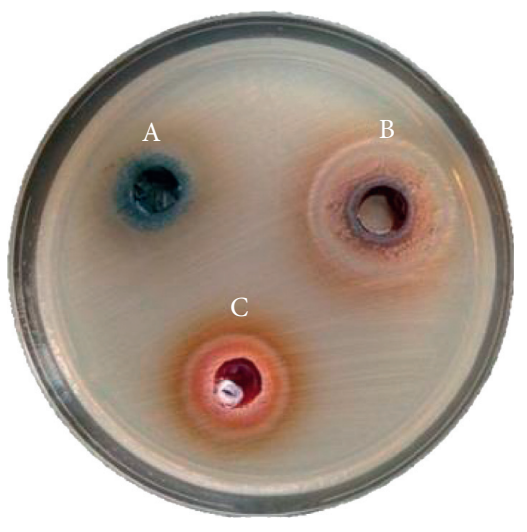

(d)

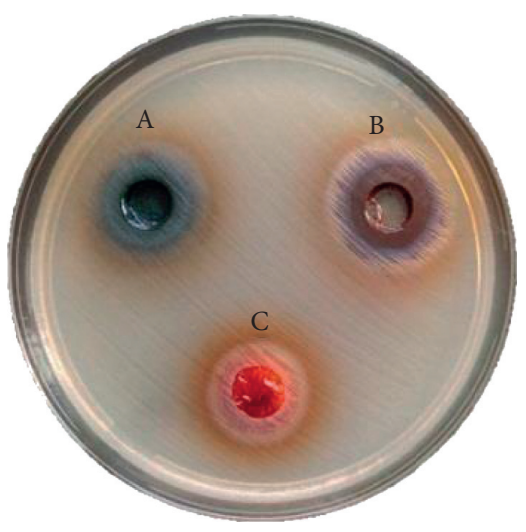

(b)

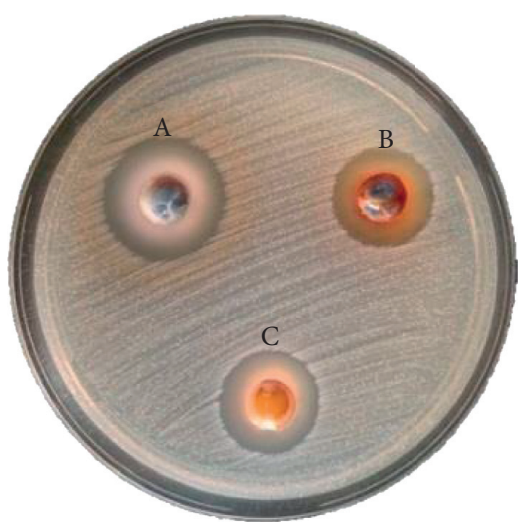

(e)

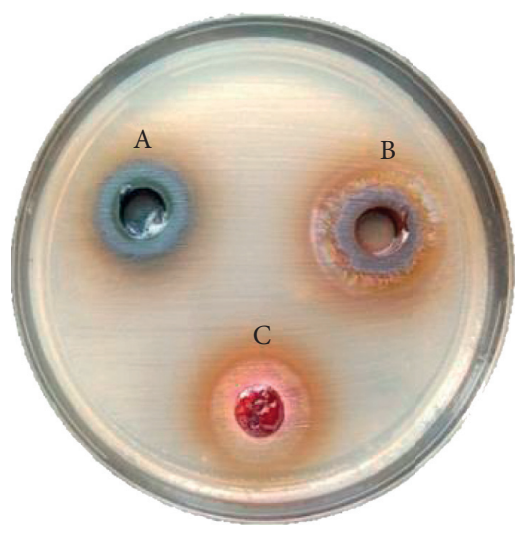

(c)

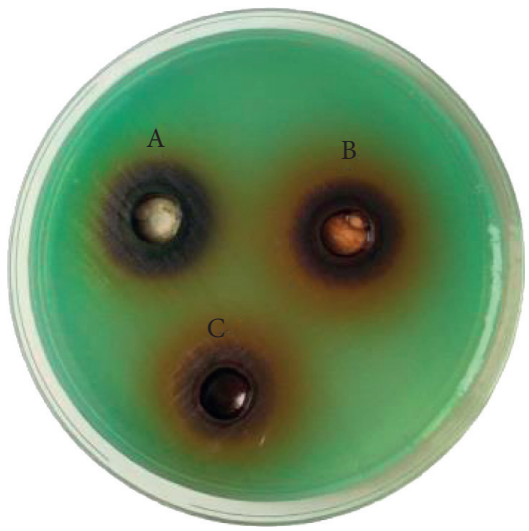

(f)

FIgURe 1: Zones of inhibition of Jatropha latex against MDR bacteria: (a) ESBL-Klebseilla pneumonia, (b) ESBL-E. coli, (c) CRE E. coli, (d) KPC, (e) MRSA, (f) CRPA, (A) J. curcas, (B) J. gossypilofia Linn., and (C) J. multifida.

TABLE 1: Diameters of zones of inhibition of Jatropha latex against MDR bacteria (mm).

\begin{tabular}{|c|c|c|c|c|c|c|}
\hline Sample & ESBL-producing K. pneumoniae & ESBL-producing E. coli & CRE-E. coli & KPC & MRSA & CRPA \\
\hline J. curcas & 0 & 0 & 0 & 0 & 23.7 & 15 \\
\hline J. gossypilofia Linn. & 0 & 0 & 0 & 0 & 20.6 & 13 \\
\hline J. multifida & 0 & 0 & 0 & 0 & 20.4 & 12 \\
\hline
\end{tabular}

TABle 2: MIC of Jatropha latex against MDR bacteria (\%).

\begin{tabular}{lccrr}
\hline Sample & MIC & \multicolumn{2}{c}{ MBC } & MRSA \\
\hline J. curcas & MRSA & CRPA & 6.25 & 50 \\
J. gossypilofia Linn. & 3.12 & 25 & 12.5 & 50 \\
J. multifida & 6.25 & 25 & 0.39 & 50 \\
\hline
\end{tabular}

inhibition ( $\mathrm{mm}$ ) against the MDR organism. In microdilution method, susceptibility test in 12 well microtiter plates contained various concentrations $(50,25,12.5,6.25,3.12,1.56$, $0.78,0.39,0.19,0.09,0.04$, and $0.02 \%$ ) of Jatropha latex. Then, the standardized numbers of MDR bacteria were inoculated into the wells of the microtiter plates and incubated at $35 \pm 2^{\circ} \mathrm{C}$ for $16-20 \mathrm{~h}$. The MIC value was observed as the lowest concentration where no viability was detected in the wells after incubation. Wells in MIC assays were subcultured using a $10 \mu \mathrm{L}$ inoculating loop onto a BAP at $35 \pm 2^{\circ} \mathrm{C}$ for $16-20 \mathrm{~h}$ incubation. The MBC was defined as the lowest concentration of the extract that did not permit any growth.

The latex of Jatropha showed antibacterial activities against the MRSA and CRPA. All latex of Jatropha showed the 


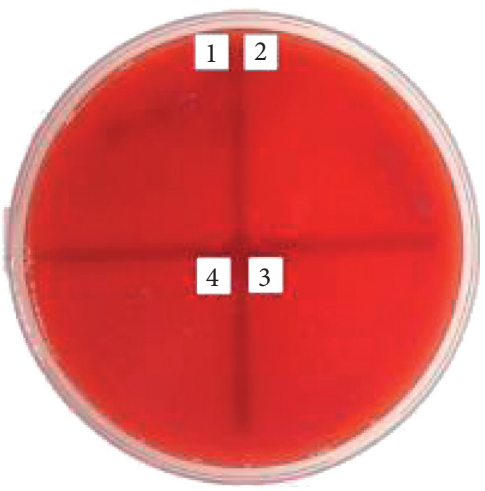

(a)

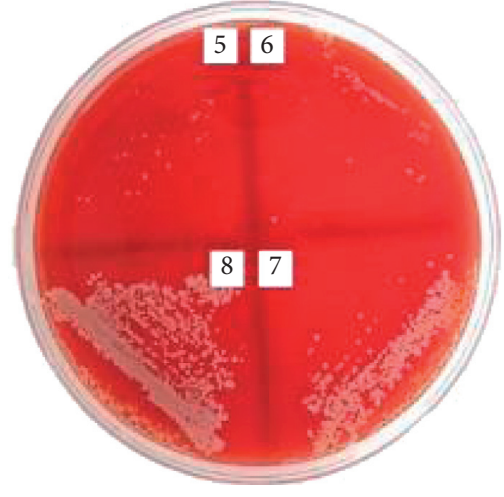

(b)

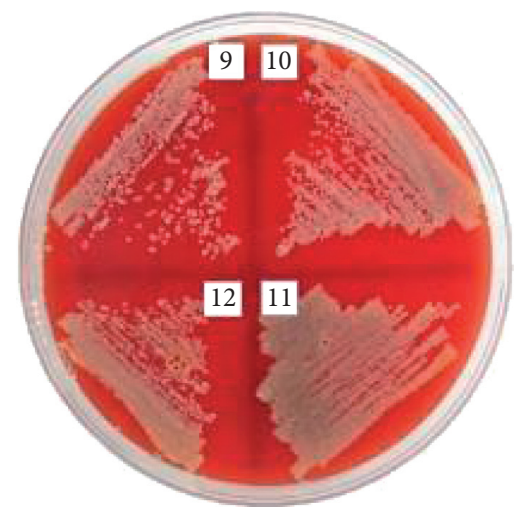

(c)

Figure 2: MBC value of $J$. curcas against MRSA at $6.25 \%$.

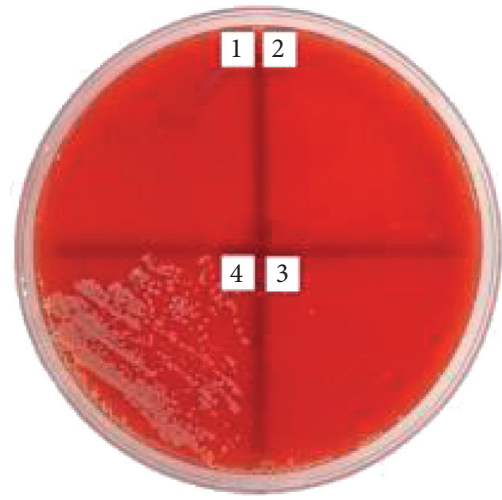

(a)

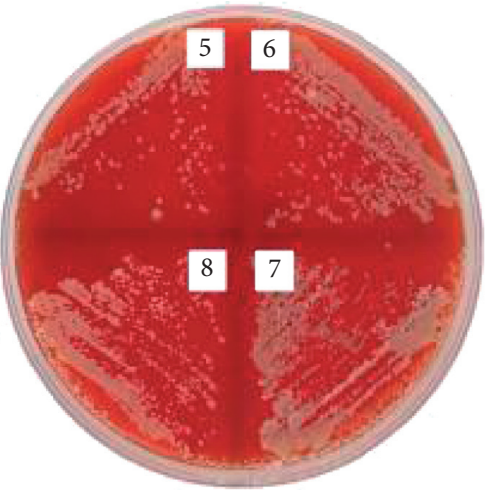

(b)

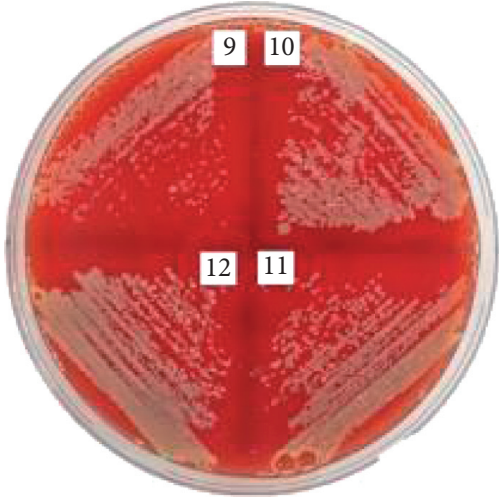

(c)

FIgURE 3: MBC value of J. gossypilofia Linn. against MRSA at $12.5 \%$.

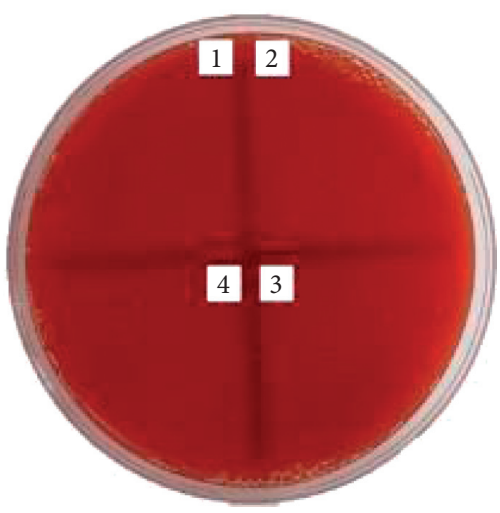

(a)

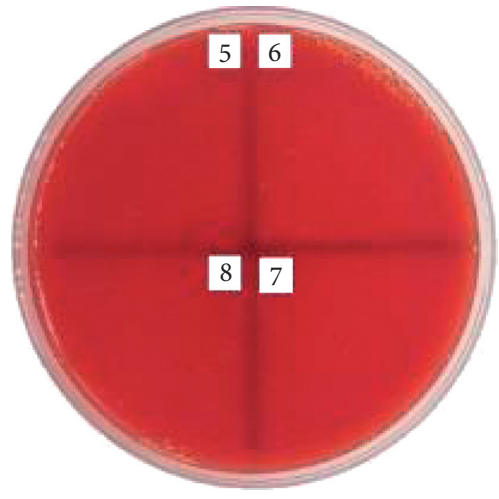

(b)

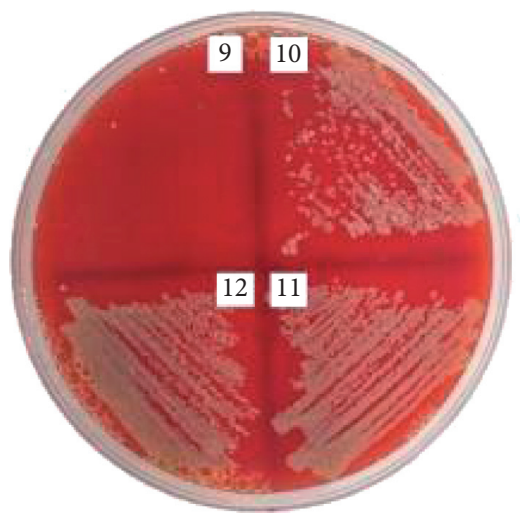

(c)

FIgURE 4: MBC value of J. multifida against MRSA at $0.39 \%$.

antibacterial activities against MRSA and CRPA in the diffusion method (20.4-23.7 $\mathrm{mm}$ and 12-15 mm), MIC (0.19-6.25\% and 25\%), MBC (0.39-12.5\% and 50\%). These results are following the research report by Hernandez-Hernandez [13] that the latex of Jatropha neopauciflora Pax demonstrated inhibition against S. aureus. In another study, the latex of Jatropha curcas displayed potent antimicrobial activity against Pseudomonas aeruginosa [14]. Phytochemical screening of latex showed the 


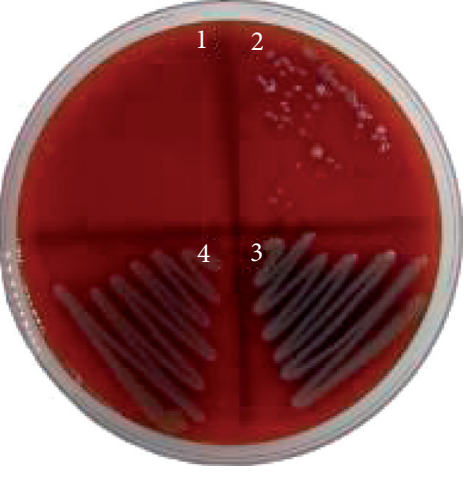

(a)

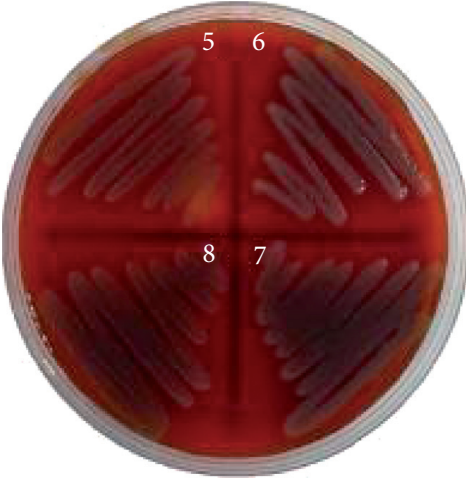

(b)

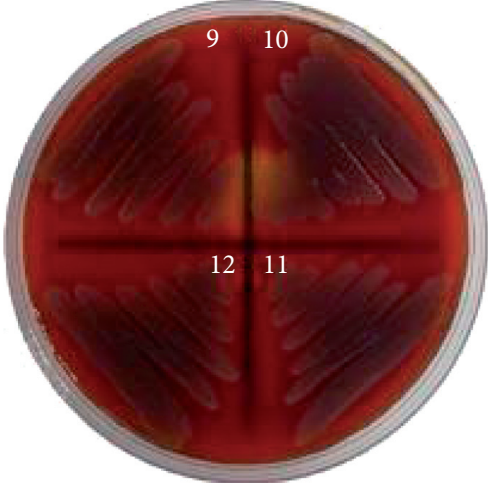

(c)

Figure 5: MBC value of $J$. curcas against CRPA at 50\%.

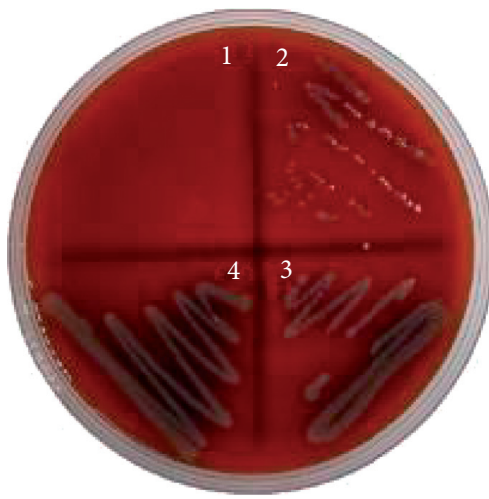

(a)

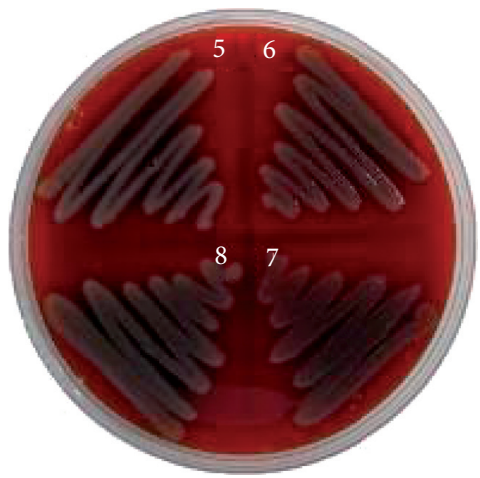

(b)

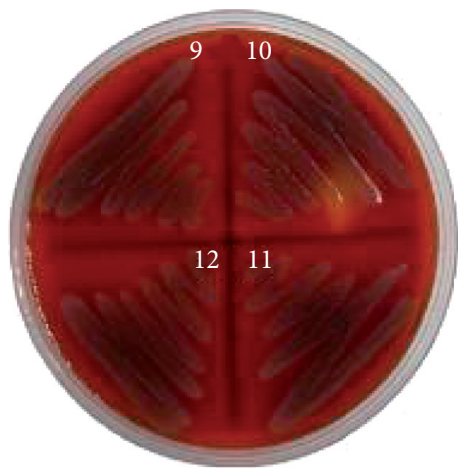

(c)

FIGURE 6: MBC value of J. gossypilofia Linn. against CRPA at 50\%.

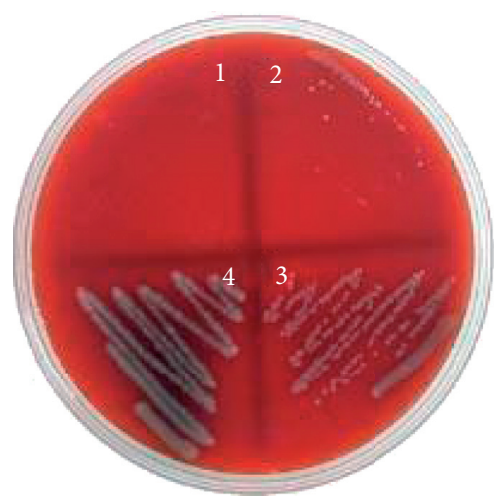

(a)

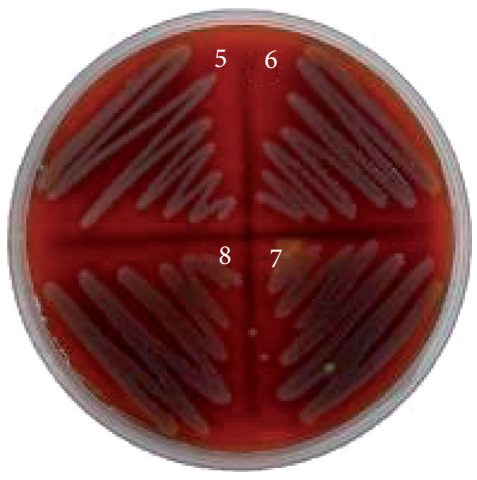

(b)

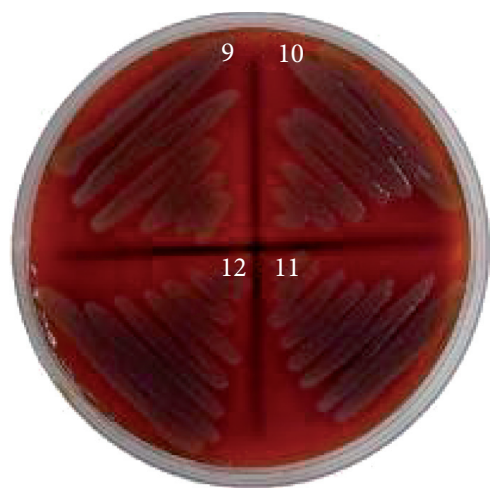

(c)

Figure 7: MBC value of J. multifida against CRPA at 50\%.

TABLE 3: Results of phytochemical analysis of Jatropha latex.

\begin{tabular}{lccc}
\hline \multirow{2}{*}{ Sample } & \multicolumn{3}{c}{ Secondary metabolites } \\
& Flavonoid & Terpenoids & Alkaloids \\
\hline J. curcas & + & - & - \\
J. gossypilofia Linn. & + & - & - \\
J. multifida & + & - & - \\
\hline
\end{tabular}

presence of flavonoids. These flavonoid compounds have been reported to be used by plants for protection against bacteria and are responsible for antimicrobial activity [15]. The latex of $J$. curcas, J. gossypilofia Linn., and J. multifida has the potential to be developed as anti-MDR-bacterial agents, especially against MRSA and CRPA strain, but further in vivo research is still needed to explicate on the effects. 


\section{Conclusion}

The latex of J. curcas, J. gossypilofia Linn., and J. multifida is prospective for development as an antibacterial agent, especially against MRSA and CRPA strain, but advanced in vivo research and discovery of the mode of its action are necessary to throw light upon the effects.

\section{Data Availability}

The data used to support the findings of this study are included within the article.

\section{Conflicts of Interest}

The authors declare that they have no conflicts of interest.

\section{Acknowledgments}

The authors are grateful to the Department of Medical Laboratory Technology, Universitas Muhammadiyah Semarang, Indonesia, for providing essential facilities for carrying out the study.

\section{References}

[1] C. Gyles, "The growing problem of antimicrobial resistance Le problème grandissant de l'antibiorésistance Carlton," CVJ, vol. 52, no. 8, pp. 817-819, 2011.

[2] C. G. Bologa, O. Ursu, T. I. Oprea, C. E. Melançon, and G. P. Tegos, "Emerging trends in the discovery of natural product antibacterials," Current Opinion in Pharmacology, vol. 13, no. 5, pp. 678-687, 2013.

[3] D. E. Djeussi et al., "Antibacterial activities of selected edible plants extracts against multidrug-resistant Gram-negative bacteria," BMC Complementary and Alternative Medicine, vol. 13, no. 164, pp. 1-8, 2013.

[4] WHO, Antimicrobial Resistance Global Report on Surveillance, WHO, Geneva, Switzerland, 2014.

[5] M. E. Prastiyanto, A. Setyaningtyas, L. Trisnawati, and A. Syafira, "Antimicrobial activity and identification the compounds of methanol extract from the pleurotus ostreatus fruiting body," El-Hayah, vol. 6, no. 1, pp. 29-34, 2016.

[6] M. E. Prastiyanto, F. A. Wardoyo, W. Wilson, and S. Darmawati, "Antibacterial activity of various extracts of averrhoa bilimbi against multidrug resistant bacteria," Biosaintifika, vol. 12, no. 2, 2020.

[7] C. Perez, M. Pauli, and P. Bazerque, "An antibiotic assay by agar well diffusion method," Acta biologiae et medicinae experimentalis, vol. 15, pp. 113-115, 1990.

[8] A. M. Saviano and F. R. Lourenço, "Using image analysis to determine gentamicin potency by agar diffusion microbiological assay and its measurement uncertainty," Measurement, vol. 146, pp. 315-321, 2019.

[9] CLSI, M100 Performance Standards for Antimicrobial Susceptibility Testing, CLSI, Wayne, PA, USA, 29th edition, 2019.

[10] C. Yin, L. Xie, and Y. Guo, "Phytochemical analysis and antibacterial activity of Gentiana macrophylla extract against bacteria isolated from burn wound infections," Microbial Pathogenesis, vol. 114, pp. 25-28, 2018.

[11] O. N. Irobi and S. O. Daramola, "Bactericidal properties of crude extracts of Mitracarpus villosus," Journal of Ethnopharmacology, vol. 42, no. 1, pp. 39-43, 1994.
[12] A. Wadood, "Phytochemical analysis of medicinal plants occurring in local area of mardan," Biochemistry and Analytical Biochemistry, vol. 2, no. 4, pp. 2-5, 2013.

[13] A. . Hernandez-Hernandez, "Antimicrobial and anti-inflammatory activities, wound-healing effectiveness and chemical characterization of the latex of Jatropha neopauciflora Pax," Journal of Ethnopharmacology, vol. 23, no. 204, pp. 1-7, 2017.

[14] M. O. Arekemase, R. M. . Kayode, and A. . Ajiboye, "Antimicrobial activity and phytochemical analysis of Jatropha curcas plant against some selected microorganisms," International Journal of Biology, vol. 3, no. 3, 2011.

[15] S. Kumar and A. k. Pandey, "Chemistry and biological activities of flavonoids: an overview," The Scientific World Journal, vol. 2013, Article ID 162750, 16 pages, 2013. 